\title{
VIRTUAL LEARNING APPLYING EDUCATIONAL STRATEGIES IN TIMES OF COVID-19; CASE OF TECHNOLOGY IN MILITARY SCIENCES
}

\author{
Flor Emperatriz Garcés Mancero, Magaly Margarita Narváez Ríos, \\ Luis Germánico Gutiérrez Albán, \& Víctor Danilo Lazo Alvarado \\ Departamento de Seguridad y Defensa; Universidad de las Fuerzas Armadas ESPE (Ecuador)
}

\begin{abstract}
The educational system in times of pandemic has had to transform itself urgently and unexpectedly to a virtual modality. This paper presents an exploratory study on the main difficulties encountered in the Soldiers Training School "Vencedores del Cenepa", where the objective of this work was to expose some strategies mediated by ICTs, for the virtualization of the teaching-learning process; When the didactic and functional methodology was applied in virtual education, I necessarily involve externalizing the demands of the teachings where they are enrolled; in this online educational process-COVID 19; the students of the institution consider their class grade as a basic educational tool, where the student himself,

Virtual learning behaves as an extension of the face-to-face classroom, mainly supported by technologies that allow, even remotely, activities that challenge students to produce a collective text, electronic portfolio, infographic or video that address a topic, can be worked collaboratively. in particular related to the topic of the class, they are generally more accepted by students than exercises or questionnaires whose objective is to record the content of a discipline; Therefore, we must see the opportunity that shortens the distances and enriches the teachers' process, maintaining their structure and development of methods according to reality; where the development of study programs is allowed, strengthens relationships and instills collaboration among all actors.
\end{abstract}

Keywords: Educational system, pandemic, virtual modality, Virtual learning, electronic portfolio.

\section{Introduction}

Education dignifies culture and beliefs, and everything that represents the human being; for this reason it is important in all its senses, since it transforms life and generates changes. However, in the 21st century and in the midst of a pandemic, most governments around the world have temporarily closed educational institutions in an attempt to contain the spread of the disease.COVID-19 pandemic.

The conditions of social distancing and forced confinement lead to the paralysis of educational, economic, industrial activities, both public and private in almost all nations, and we observe the impact on our daily lives in all actions and activities of the entire society.(Tárrega Astigarraga \& Palau Pellicer, 2017)

With this consideration, the different social actors that make up the IES such as students, academic manual and administrative workers and authorities, as well as other sectors of society that are related to educational units, colleges, universities and higher institutes and research centers, They have been facing with creativity and haste the challenge of the reality that we are going through, rethinking the activities planned to comply with and to give continuity to the exercise of their substantive functions and teaching activities, to continue addressing the challenges and problems they faced since before the COVID-19 crisis will break out.

When the COVID-19 pandemic arrived in Ecuador, at the Soldiers Training School "Vencedores del Cenepa", nothing was planned, they were only mere assumptions of the situations that were coming, in addition to the expectation of the applicants of uncertainty, if they stay in the institution or if they return home; But no one clarified the panorama, of course, of course, in the same way the teachers who provide services in the school, as occasional teachers and guest teachers.

On March 18, 2020, the students of the Military Sciences Technology Career belonging to the University of the Armed Forces - ESPE, are sent to their homes, for better connectivity in the classes and to comply with the periods established for the training of Technologists; In other words, the educational system must continue to guarantee this online teaching-learning process and the right to study in this new 
scenario; However, not all have the necessary materials in their homes to start this migration to virtual education.

Possibly there will be concern in some cases of vulnerable students, who do not have connectivity and technological devices in their homes, by virtue of the fact that in ESFORSE there are applicants with low economic possibilities, which makes it a great challenge for educational equity. In this sense, the following unknowns arose: Is the training school prepared to generate a teaching-learning process in a virtual way? Do parents have the economic possibilities and technological tools necessary for their children to achieve the acquisition of new knowledge, for the present academic challenge?; From these questions in mention arises the need to answer the main question that is knowledge;

The following specific objectives emerge from these forecasts: (a) investigate the perception of education today; (b) identify the challenges of the Soldiers Training School; "Vencedores del Cenepa", in this new setting. These objectives gave rise to the central purpose of the research which was to identify the challenges of the institution in the context of the COVID-19 pandemic, mainly from information and communication technologies and interrelated with the methodology of the educational process.

\section{Virtual learning: The applicant and the teacher}

The suspension of face-to-face teaching activities gave way to virtualization, where teachers and students had to adapt to a new educational context. In addition, the turn to this online teaching has been sudden, ignoring the long training processes, redesign of subjects and infrastructures that support the demand for tele-teaching (González-Calvo et al., 2020).In fact, in several Latin American countries, COVID-19 had a negative influence on the teaching-learning process, due to the fact that for many years there was no investment in the adaptation of virtual campuses, institutional websites, digital scientific journals and in the training of teachers and students in the use of ICTs, having to improvise technological solutions (Ríos Campos, 2020).

\section{Adaptation of the methodology: Means and Procedures}

At the institutional level, the ESPE published a resolution on July 9, 2020, where it approved the Study Guide Methodology to Develop the academic activities of the subject through learning, in which it established Academic criteria for the adaptation of the classroom teaching format to the not face-to-face, guaranteeing the achievement of the competencies programmed for the course in the context of the state of alarm generated by Covid-19.

The activities that were planned to be carried out in person have become e-activities without having had enough time to adapt them properly; When the didactic and functional methodology is applied in virtual education, it necessarily involves externalizing the demands of the teachings where they are enrolled; in this online educational process-COVID 19; where the students of the institution consider their classroom grade as a basic educational tool, perhaps it is sought that the applicant himself now, awakens his creativity, constitutes a didactic complement to the study and a support to the teaching-learning process through the different tools and materials available supplementary materials, research resources, others.

The virtualization of direct educational materials involves the application of the main quality criteria that guarantee an efficient accessibility to the materials, the cognitive economy and the acquisition of knowledge; where automation in the creation and publication of online educational resources, which obviously guarantee a high production with minimal human and technical resources, must never forget the peculiarities of the discipline and the needs of the members involved in this process: authorities, teachers and aspirants; the main objective being the transmission of knowledge and reaching a meaningful learning.

\section{Conclusions}

Virtual learning from home during the COVID-19 pandemic has had a significant impact on the education systems of all countries in the world. In response to this crisis, countries have applied different rules and methods to deal with changes in the apprenticeship system. In a few months, the national educational systems resorted to solutions such as online methods, conscious of creating an active system that favors interest, personal motivation, reflection, responsibility, creativity and sharpening the understanding of the contents taught. in virtual form; where the student became an actor of his own education, favoring his intelligence to increase, through problematic situations inherent to his military professional profile. 
The situation caused by Covid-19 has opened the door to the generation of teaching and methodological innovation by all teachers. The chosen methodologies have raised in some cases the need to rethink the reduction of the contents of the subjects compensated by the activities to be carried out by the students that allow to complement or specify the theoretical aspects explained.

Although it is true, it is the opportunity to use strategies in pedagogy, didactics and evaluations; through distance learning, with the use of technological formats and platforms, generating an adequate environment for the health, psychological and economic well-being of students; projecting new opportunities for learning and educational innovation, after having overcome the crisis generated by the pandemic.

The student-applicants belonging to the Career of Technology in Military Sciences complied with the planning established in the Curriculum Mesh through the technological methodologies used by teachers, thus fulfilling their role in the teaching-learning process within their professional training to the student.

\section{References}

https://plus.google.com/+UNESCO. (2020, March 4). Education: From disruption to recovery. UNESCO.https://en.unesco.org/covid19/educationresponse

https://plus.google.com/+UNESCO. (2017, September 21). Education in crisis situations. UNESCO.https://es.unesco.org/themes/educacion-situación-crisis

González-Calvo, G., Bores-García, D., Barba-Martín, RA, \& Gallego-Lema, V. (2020). Learning to be a teacher without being in the classroom: COVID-19 as a threat to the professional development of future teachers. International and Multidisciplinary Journal of Social Sciences, 9 (2), 152-177. https://doi.org/10.17583/rimcis.2020.5783

Millán, T., Heresi, C., Díaz, F., Weisstaub, G., \& Vargas, NA (2020). The covid-19 pandemic as a reflection opportunity in health sciencies education. Revista Chilena de Pediatria, 91 (4), 489-491. https://doi.org/10.32641/rchped.vi91i4.2784

Olmedo Plata, JM (2020). Learning styles and school academic performance from the cognitive, procedural and attitudinal dimensions. Learning Styles Magazine, 13 (26), 143-159.

Pallisé, JS, González, CB, i Verges, CB, \& i Daniel, MB (2016). Blendedness in Higher Education: Case Studies in the Degrees of the University of Barcelona. EDUTEC. Electronic Journal of Educational Technology, 58, 15-33. https://upo.es/revistas/index.php/IJERI/article/view/5015

Ríos Campos, C. (2020). COVID-19 and Public University Higher Education of Peru. Clake Education Magazine, 1, 1-1.

Ruiz, ABM (2010). ICT teacher training Are teachers prepared for ICT (R) evolution? International Journal of Developmental and Educational Psychology, 4 (1), 35-44.

Tárrega Astigarraga, O., \& Palau Pellicer, P. (2017). Plastic and visual education in contemporary art spaces. Research Forum, 19, 239-258. https://doi.org/10.6035/forumrecerca.2014.19.17

Tejedor, S., Cervi, L., Tusa, F., \& Parola, A. (2020). Education in times of pandemic: reflections of students and teachers on virtual university education in Spain, Italy and Ecuador. Revista Latina, 78, 1-21. https://doi.org/10.4185/rlcs-2020-1466

Vite Cevallos, H., Carvajal Romero, H., Samaniego Ocampo, R., \& Prado Ortega, M. (2020). Virtual competencies of teachers in the face of the Covid-19 challenge in higher education institutions in Ecuador. Revista Conrado, 16 (S 1), 178-183. 